\title{
The Relationship between IHL and IHRL in Peacekeeping Operations: Articulating the Emerging AU Position
}

\author{
James Fowkes* \\ University of Pretoria \\ james.fowkes@aya.yale.edu
}

\begin{abstract}
* LLM, JSD (Yale). Senior researcher, Institute for International and Comparative Law in Africa, University of Pretoria, South Africa. Research for this article was supported by the South African National Research Foundation, grant no 81358. The author is grateful to Erika de Wet, Michaela Hailbronner, Bruce "Ossie" Oswald, Daphna Shraga and an anonymous reviewer for their comments on earlier drafts of this article. Responsibility for any remaining errors is the author's.
\end{abstract}

\begin{abstract}
Modern peacekeeping is increasingly expansive, and much of it occurs in Africa. The African Union's attitude to the challenges of regulating this modern peacekeeping is therefore an important source for the associated legal debates, but one that is often neglected (in part because the sources are limited and often in draft form). This article seeks to articulate and then critique the AU's emerging view on the application of international humanitarian law and international human rights law to peacekeeping activity and the relationship between the two bodies of law in this context. It argues that the AU's emerging position treats international humanitarian law as a narrowed lex specialis, only displacing international human rights law in relation to peacekeepers while they are actively engaged in armed conflict. Even this position, however, underestimates the extent to which the pervasive rights-based concerns in AU sources imply a still more pervasive application of international human rights law to its peacekeeping activities.
\end{abstract}

\section{Keywords}

International humanitarian law, international human rights law, lex specialis, peace-keeping, African Union

\section{INTRODUCTION}

Peacekeeping in Africa today is characterized by three things: its unusual prevalence in world terms, unusually expansive nature by historic standards, and rather uncertain legal status. Considering the stakes of peacekeeping (its use of deadly force, familiar abuses and potential contributions), this last point is especially worrying.

The uncertainty has multiple causes, including the youth of the African Union (AU) and the nascent state of many of its internal arrangements, the broader unanswered questions surrounding modern expansive forms of peacekeeping, and the several bodies of law and institutional arrangements that find potential application to the activities of peacekeepers. This article explores one aspect of the uncertainty: the relationship between international 
human rights law (IHRL) and international humanitarian law (IHL) in this context, from the under-examined perspective of the emerging position of the AU on the issue. The AU's approach to peacekeeping (and related topics of security and state-building) is increasingly expansive. If the Organisation of African Unity was notable for its strong emphasis on nonintervention, the $A U$ appears to be leaning the other way. ${ }^{1}$ Article $4(\mathrm{~h})$ of the $A U$ Constitutive Act, as is well known, asserts an AU power to intervene in African countries in response to "war crimes, genocide and crimes against humanity" even in the absence of a UN mandate. ${ }^{2}$ There is a proposal to expand this list by adding the text "as well as a serious threat to legitimate order to restore peace and stability to the Member State of the Union". ${ }^{3}$ This remains only a proposal, but it exemplifies the ambitious framework that is emerging for peace support operations (PSOs). That framework encompasses everything from stopping genocide to restoring failed states, from preventing conflict, to managing it, to ending it decisively and rebuilding after it. ${ }^{4}$ It calls on PSO personnel to fulfil all these tasks in the notoriously complex environment of peacekeeping, where conflict can be sporadic, peacekeeper involvement in conflict can also be sporadic, and "combatant" and "noncombatant" can be slippery categories when military tasks often have to be fulfilled alongside non-military ones and by the same people. Moreover, this AU activity takes place against the backdrop of similarly expansive attitudes to peacekeeping at the UN level. In recent years the UN Security Council has mandated the use of active, offensive force by peacekeepers in Africa, with the interventions in Somalia, Côte d'Ivoire, Burundi, the Democratic Republic of the Congo (DRC) and the Central African Republic all being important examples. ${ }^{5}$ The Strategic Intervention Brigade, deployed as part of the DRC mission beginning in 2013, tests the boundaries of traditional ideas of peacekeeping with its active offensive mandate to "neutralize" armed groups threatening civilians. ${ }^{6}$ More general UN statements, such as Capstone, ${ }^{7}$ reflect a similarly robust attitude to peacekeeping and have evidently influenced the African approach, as we will see.

Given the scope of developments and of the use of force in African countries that they entail, it is important to consider how this activity is to be regulated (even if resource limitations are likely to constrain its more ambitious manifestations in the foreseeable future). ${ }^{8}$ Attention in this area, especially in the African context, is often focused on interventions in response to the gravest acts (genocide, war crimes, crimes against humanity) that are the focus of international criminal law and the Responsibility to Protect. ${ }^{9}$ In the context of these topics, the relationship between IHL and IHRL is probably of technical interest only: the gravest acts are readily categorized both as gross IHRL violations and as paradigm examples of violations of customary $\mathrm{IHL}$, so the substantive answer is the same whatever the formal one. ${ }^{10}$ However this changes once one moves beyond the most serious abuses, when IHL starts to permit things that IHRL will not, and when the debates begin about IHL's status as a lex specialis [a specific law that prevails over general law] and the precise extent of the application of IHRL in conflict situations. ${ }^{11}$ The AU's emerging thinking on these issues is quite limited and tentative, as one might expect in a new area, and its focus is not always primarily on legal issues. However, it nevertheless repays serious engagement, especially given the global uncertainty on these questions. As the site of much the greatest portion of the new peacekeeping activity, the African contribution is important, and some of the $\mathrm{AU}$ documents reflect an intention to rise to meet this challenge. This article's attempt to articulate and critique the AU's emerging thinking is conducted in the same spirit. 
Although the argument takes account of a wider range of documents, the principal focus here is on the draft doctrine developed for the African Standby Force's ${ }^{12}$ involvement in PSOs (Doctrine). ${ }^{13}$ The draft is a book-length document and is easily the most extensive engagement with the challenges of modern peacekeeping in Africa that has been produced under the auspices of the AU. ${ }^{14}$ Although in fact it says little explicitly about IHL, IHRL and their relationship (and does not generally have a particularly legal focus), somewhat more is suggested or implied. This article works through a series of possible legal framings of how the Doctrine appears to understand the relationship between IHRL and IHL in the regulation of PSOs. Having attempted to articulate its view of the legal position, the article shifts into a more critical gear and presents refinements to that framing in light of some broader legal issues and concerns.

\section{INSTITUTIONAL AND LEGAL BACKGROUND ISSUES}

Before turning to this close analysis, however, it is important to place the Doctrine in the broader context of AU developments and of the surrounding legal landscape.

A natural starting point for guidance on the legal regime for $A U$ peacekeeping is the $A U$ Peace and Security Council (PSC). The PSC has authority to "undertake peace-making and peace-building missions" and, most pertinently here, bears the related responsibility to "lay down general guidelines for the conduct of such missions, including the mandate thereof, and undertake periodic reviews of these guidelines". ${ }^{15}$ However the PSC has yet to issue any guidelines in this area. The greatest focus of its attention remains on setting up the elements of the African Peace and Security Architecture (the PSC itself, the Panel of the Wise, the Continental Early Warning System, the African Standby Force and the transitional African Capacity for Immediate Response to Crises) and building relationships between them, and between African institutions and the UN, African regional organizations and other entities such as the EU. ${ }^{16}$ The PSC also has limited capacity. It has commented that "since 2004, when the PSC started operating, [it has] remained very thin in human resources and has consequently become overloaded". ${ }^{17}$ In addition, in this area the AU generally has had to "build the ship while already at sea". The AU Commission has noted the "additional challenge" that "while the continent is making efforts to put the building blocks of the African Peace and Security Architecture ... in place", it has "face[d] the obligation of undertaking peace support operations at the same time". ${ }^{18}$

For this reason, an enquiry into the AU's thinking on peacekeeping cannot, at this stage, confine itself to the blackest of black letter sources. The author has therefore surveyed the documents filed under the relevant headings in the online resource library maintained by the PSC and taken into account press statements and internal documents such as reports of meetings and communiqués. ${ }^{19}$ Furthermore, two of the most interesting sources are both still in draft form. This rather liberal approach to legal sources, something that should be kept in mind when reading this article, is not only unavoidable at this stage, but also yields conclusions of greater significance than may appear at first glance. ${ }^{20}$ The AU has placed a strong emphasis on harmonizing its peace and security infrastructure with UN systems and expectations. It also depends heavily on external funding and thus seeks to appeal to other actors, including the EU and the G8. ${ }^{21}$ As a result, the AU has powerful incentives to comply with modern expectations about peacekeepers, whether or not those expectations amount 
to formal obligations binding upon it. Internal AU documents attempting to meet these expectations may therefore have a practical significance that far exceeds their status in formal legal terms.

Another natural place to start the enquiry would be with the external legal regimes that bind the $A U$, and here other limitations emerge. The $A U$ is not a state and is not a party to the Geneva Conventions or key IHRL instruments. It must therefore be acknowledged that the application of IHL and IHRL to AU peacekeeping missions is not legally straightforward. In addition, the scope and application of IHL are generally more limited and more contested in the context of non-international armed conflicts, the setting for most contemporary African peacekeeping missions. ${ }^{22}$

Issues such as these are naturally important, but this article will mostly not attempt to engage the debates to which they give rise. For one thing, as we will see, the AU's engagement with the issue to date does not usually descend to these details either: it chiefly grapples with the potentially simultaneous application of the two bodies of law, rather than details such as the variegations of IHL in different kinds of conflicts. ${ }^{23}$ For another, while the application of IHL and IHRL to AU peacekeeping might not always be legally straightforward, it is hardly far fetched either. There are a variety of plausible grounds for applying IHL and IHRL to AU peacekeeping. First, there is an important body of customary law. Secondly, recent peacekeeping missions in Africa that use significant force have occurred under UN Security Council mandates that provide for the application of IHL and IHRL to those missions (though invariably not exactly how and when they apply or how the two bodies of law relate to each other). Thus in the African examples where peacekeeping force is of the level where its regulation under IHL might arise, the question of whether IHL and IHRL apply is often already answered. Thirdly, while the general UN position contains many uncertainties, the debate today is not about whether IHL applies to UN peacekeeping, but rather whether the UN is strictly bound by the rules of IHL or only by its "principles and spirit", and how that answer might change depending on the kind of armed conflict and the nature of the intervention. The same is also often true for contemporary discussions of the application of IHRL, which tend to focus on working out the details of its relevance to peacekeeping activity rather than debating whether it has any. ${ }^{24}$ Fourthly, there are a number of contestable but nevertheless weighty arguments that the $A U$ is bound by IHL and IHRL, although it falls outside the scope of this article to consider them in detail. (The issue has received little consideration in relation to the $A U$ but analogies are readily drawn to arguments made in other contexts.) ${ }^{25}$ Thus one could mount the argument that the $\mathrm{AU}$ should not be able to act contrary to its own founding purposes. For example, the AU Protocol on the PSC, the key actor in the peacekeeping context, bears the duty to "promote" "respect for ... international humanitarian law" and to ensure AU member state compliance with $\mathrm{IHL} ;{ }^{26}$ it would seem inconsistent with these duties for the PSC itself not to comply with IHL in its peacekeeping and other responsibilities. One could argue that the $A U$ should be taken to have assumed these obligations by virtue of a unilateral undertaking to be bound by them, although it is not clear that the AU has yet made such an undertaking in respect of any major category of IHL or IHRL. Currently, the closest it has come to such unilateral undertakings is, arguably, in relation to the mandates of its operations with the UN, which are of course also confined to the mission in question. One could also argue that African countries, which have overwhelmingly bound themselves 
to the treaties considered in this article, cannot be held to evade their own legal responsibilities simply by having the AU carry out peacekeeping activities. ${ }^{27}$ In addition, the $A U$ itself places significant reliance on member states to train troops they contribute to peacekeeping missions. ${ }^{28}$ Thus, in the AU's view, at least those aspects of IHL or IHRL obligations that are discharged by training will importantly be borne by African states bound by those bodies of law. This category of obligation will thus find application to AU peacekeeping missions even if it were held not to bind the AU itself.

The significance of all these arguments for the present purposes is simply that it is neither outlandish nor abstract to depart from the premise that IHRL and IHL have significant relevance to $\mathrm{AU}$ peacekeeping missions and to focus on the subsequent investigation into the AU's emerging views of exactly what that relevance is. It is precisely because there would be broad general agreement that the $A U$ and its member states stand to incur international responsibility if they do not comply with IHL and IHRL in peacekeeping activities that the legal details merit attention.

\section{THE DRAFT GUIDELINES FOR THE PROTECTION OF CIVILIANS}

The draft Guidelines for the Protection of Civilians (Guidelines) are much briefer than the Doctrine considered below, but they merit brief mention here. They are the product of a special commission whose mandate is apparent from its title: the Commission on the Development of Guidelines for the Protection of Civilians in African Union Peace Support Operations. The commission is distinct from but operates in collaboration with a number of AU organs, including the PSC, the Departments of Political Affairs and Social Affairs, the Women, Gender and Development Directorate, and the Office of Legal Counsel.

The Guidelines, issued in 2011, are significant above all for the position they assign to rights. On the one hand, they state that "[r]ights-based protection must be applicable to both individuals and groups and must be mainstreamed from the outset". ${ }^{29}$ That would seem to support the view that IHRL is of pervasive application, regardless of the situation. On the other hand, the elaboration offered of this is modest, albeit also open-ended: "[a] rightsbased approach can involve the monitoring and reporting of human rights violations" in the vicinity of peacekeepers as well as "the development of local capacity to promote and protect human rights". ${ }^{30}$ That does not preclude a greater role for rights, but the Guidelines appear to think of the protection of civilians, and the associated human rights obligations, as something that happens alongside a conflict but is somehow separate from the actual fighting. There is no explicit suggestion that rights bind peacekeepers who use force, as opposed to being relevant to some of the aspects of the broader mission. The Guidelines do not even mention IHL or the conduct of hostilities.

The draft is a brief document and so the discussion is necessarily limited, although the degree to which the document does not consider legal questions is notable. These features of it will be rather better understood, however, once we examine the second and considerably more elaborate source. 


\section{THE DRAFT AFRICAN STANDBY FORCE PEACE SUPPORT OPERATIONS DOCTRINE}

The third meeting of African chiefs of defense staff, held in Addis Ababa on 15 and 16 May 2003, contemplated the development of a doctrine for the African Standby Force. ${ }^{31}$ A final draft of the Doctrine (together with a draft training policy) was produced in November 2006, but neither has yet been formally adopted.

\section{Links to human rights}

Since the Doctrine tends to be rather more uncertain about the application of IHRL to peacekeeping than about IHL (as is also true in the UN context), ${ }^{32}$ it is useful to begin with the links the Doctrine does make to human rights. Its most explicit references are made in connection with the objectives of PSOs. According to the Doctrine, "[a]II PSOs have at their root the aspiration to improve the lot of those who are suffering in a crisis zone. More specifically humanitarian operations are conducted to alleviate human suffering". ${ }^{33}$ This concern has natural links to IHRL and the Doctrine makes this explicit even in relation to PSOs that use significant military force. The Doctrine again follows UN terminology in referring to this variety of PSO as a "peace enforcement operation", and it notes that in such contexts:

"... the link between military and political [ie those set by the mission's civilian mandators] objectives must be extremely close. It is important to emphasize that the aim of the [peace enforcement] operation will not be the defeat or destruction of factions of belligerents, but rather to compel, coerce and persuade the parties to comply with a particular course of action, ie to desist from abusing the basic right to life and dignity, and to support the peace process." ${ }^{34}$

The Doctrine links PSO objectives to human rights in three more specific ways. The first relates to international criminal law. The Doctrine speaks repeatedly of "basic violations of human rights such as ethnic cleansing". It is often transparently focused on a Rwanda-type situation "in which there are wide spread [sic] and ongoing abuses of human rights and the commission of war crimes, crimes against humanity and genocide". ${ }^{35}$ As noted, however, this is also the issue that has the least relevance to the relationship between IHL and IHRL, and this article comments no more on this aspect of the doctrine.

The second specific IHRL link mentioned by the Doctrine relates to gender issues and to children, a very significant area for the relationship between IHL and IHRL. However, much of what is important turns on details of the particular IHRL instruments concerned, with which the Doctrine does not engage. (The AU Commission has noted the "short term" need to supplement this aspect of the Doctrine.) ${ }^{36}$ This analysis of these instruments is a paper in itself, which the author takes up elsewhere. ${ }^{37}$ This gap in the Doctrine's legal concerns, however, is associated with an important defect in its framework, to which this article returns below.

The main interest here lies in the third kind of reference the Doctrine makes to human rights. This concerns the broader link between human rights, on the one hand, and the rule of law and the state of affairs a PSO should try to bring about, on the other. The Doctrine 
understands that PSOs, by their nature, "will generally relate to the establishment of a secure, stable and self-sustaining environment for the local population". ${ }^{38}$ It speaks of "rule of law" missions whose aims include boosting local legal institutions and meeting "rule of law and human rights standards in the mission area". ${ }^{39}$ A closely related type of intervention is understood to aim for a rapid handover to civilian authorities. The "endstate" of what is dubbed a "civilian administration mission" is the "creation of conditions for local political control and ownership of the civilian administration apparatus, in full respect of human rights, the rule of law, and good governance principles". ${ }^{40}$ These descriptions closely resemble the statement in Capstone of the end goals of "multi-dimensional" PSOs, which include to "re-establish the rule of law and strengthen respect for human rights". ${ }^{41}$ Nowhere does the Doctrine spell out exactly what is meant by its references to "human rights", but phrases like "full respect of human rights" in the context of establishing "normal" civilian authority suggest that "human rights" is being used as a signifier denoting a return to ordinary, law-bound, civilian authority.

A stance that human rights are relevant to the objectives of a mission has implications for how that mission is carried out, but these take some working out. The Doctrine itself gestures at several of these links but, as will now become evident, it does not itself perform that working out, especially in legal terms.

\section{Links to the legal regime governing PSOs}

The Doctrine gives several reasons to think that PSOs are bound by IHRL. One is purely instrumental. The Doctrine advises that PSOs should use methods "generally defined in terms of consent promotion or more traditionally as "hearts and minds' techniques" because "[a] loss of consent and a non-compliant party may limit the freedom of action of the PSO components". ${ }^{42}$ A PSO should comply with human rights because not doing so will make it unpopular and cause problems for itself. This recalls Capstone's concerns that a PSO "must work continuously to ensure that it does not lose the consent of the main parties" and that the legitimacy of a mission is based in part on how PSO personnel relate to the local population. ${ }^{43}$

However, in a peace mission, such concerns are naturally more than purely instrumental. When the Doctrine states that "[t]he actual success of the operation is related to the daily circumstances of the local populace in the former conflict area", 44 it is not just making a strategic comment about the value of supportive locals or the problems of weakening host state consent. It is referring back to the substantive aim of "the establishment of a secure, stable and self-sustaining environment for the local population". ${ }^{45}$ If a mission is undertaken for the purpose of protecting human lives and other interests, it would be selfdefeating to act with disregard for rights. ${ }^{46}$ If a mission aims to re-establish law-bound civilian order, it would be self-defeating for peacekeepers to act with reckless regard for the law or to encourage by their own actions the perception that guns are the only rules. Thus the Doctrine notes that "the creation of a self-sustaining peace requires that PSO leaders do not focus their activities exclusively on the warring factions but work to promote the cooperation and consent of those already engaged in peaceful activities". " 47 also recognizes that, if a military force aims to hand over to a civilian authority, this implies "a relatively secure environment and a certain level of consent present in the local environment". ${ }^{48}$ 
These sorts of arguments have obvious potential to ground links between IHRL and military operations or, more precisely, to ground links between the aims of a peacekeeping mission and why IHRL should continuously inform decisions about the use of military force to achieve those ends. It is readily aligned with the statement in Capstone that all UN PSO personnel "should act in accordance with human rights law and understand how the implementation of their tasks intersects with human rights". ${ }^{49}$ However, it is not clear that the Doctrine itself understands these points in terms of IHRL, and it is here that its unresolved legal implications start to become apparent. Thus, for example, in the context of discussing the importance of local consent for sustainable peace, the Doctrine states that this consent "is the basis of a philosophical approach to the use of force that limits its application to that necessary to achieve the desired outcome. This legal principle is enshrined in the Law of Armed Conflict". ${ }^{50}$

The Doctrine itself, in other words, seems to understand the importance of local consent in terms of IHL, not IHRL: it is disproportionate force, contrary to IHL, which is said to alienate the local population. This is presumably correct in its own terms, but is this an appropriate legal framing of the Doctrine's concerns?

\section{PSOs and the IHL proportionality principle}

There are at least two reasons to think that the Doctrine's substantive concerns exceed the resources of the standard IHL proportionality argument. The first is that even a proportionate military response can obviously have grievous consequences for the local population. Mere compliance with IHL rules on targeting therefore seems inadequate to the idea that a PSO should take special and constant pains not to alienate nearby civilians or domestic authorities in order to maintain legitimacy and consent. The second is that the IHL proportionality principle is a constraint based on means, not ends. The Doctrine, plausibly, seems to understand the goals of PSOs at least partly in terms of human rights. The desired outcomes are not just ordinary military objectives, but are about establishing peace and securing civilian interests. This, too, calls into question whether it is entirely satisfactory to understand the use of force by PSOs purely in terms of the standard IHL proportionality principle.

The Doctrine's real point appears to be about the use of force that is practically and in principle inconsistent with the objectives of a peace mission, rather than just the use of force that is disproportionate to that aim. The concerns of legitimacy and consent promotion are much better understood in terms of inconsistency. Of course, the "law of armed conflict" to which the Doctrine refers has resources beyond the proportionality principle. Duties towards civilians based on Common Article $3^{51}$ and other provisions could provide further legal underpinnings for the Doctrine's concerns. However, the objection nevertheless ultimately stands: the Doctrine understands PSO personnel to have greater responsibilities than those of ordinary combatants using force in an armed conflict, and this is something for which a purely IHL-based legal framing will understandably struggle to account.

This sort of argument finds resonance in other parts of the Doctrine. As will be seen in more detail later, it emphasizes the importance of military actors remaining constrained by the 
mandates issued to them by the civilian authorities. If the goals of these mandates are at least partly rights-based, then military decisions are not supposed to be isolated from this, and thus IHL alone again seems an inadequate framework. The Doctrine also understands the decision to use force in more constrained terms than would ordinarily be implied by IHL. There is an imperative to try and avoid force, echoing statements in Capstone that a UN PSO "should only use force as a last resort, when other methods of persuasion have been exhausted, and an operation must always exercise restraint when doing so ... In its use of force, a [UN PSO] should always be mindful of the need for an early de-escalation of violence and a return to non-violent means of persuasion". ${ }^{52}$

The Doctrine understands the decision to use force in similar terms. It observes that consent may be lost if a PSO uses excessive force in what is considered an illegal or inappropriate manner. However, in the same breath it refers to the Rwanda-type scenario: “... [c]redibility, linked to consent, may also be lost if the PSO does not respond to breaches of the mandate and international laws and takes no action to prevent or stop major abuses of basic human rights such as ethnic cleansing". 53

It also recognizes, in ordinary conflict situations, that "as the conflict intensifies, the need to engage the parties in dialogue will diminish until ultimately the strategic objectives specified in the mandate and political end-state could be imposed on the parties without consultation". ${ }^{54}$

A PSO, in other words, is not understood as an entity that may use force proportional to its military objectives (the standard IHL position) but as an entity that must make constant calculations about whether the use of force is compatible with its objectives as a PSO. It is understood as an entity under greater constraints in its use of force than an ordinary belligerent. It is supposed to try and avoid force, and to try and limit its use of force, to a greater degree than simply being confined to using no more force than is proportional to military objectives.

It is easier to see that this sort of calculation is not the ordinary IHL targeting principle than it is to decide what it is, legally speaking. The Doctrine, however, has a further suggestion to make here. Although there are passages where the Doctrine seems to understand itself purely in terms of the ordinary principles of IHL, there are also parts of the text that suggest a different line through the problem.

\section{A multi-dimensional PSO: Different rules for different actors}

One of the Doctrine's more striking passages, to a lawyer, is a claim about PSOs that seems to blur the terminologies of IHL and IHRL: "[t]he protection of a non-combatant's basic right to life and dignity is a fundamental element of all PSOs. The prevention of abuses to basic human rights and the imposition of justice will require a PSO that is appropriately trained and configured to such tasks". ${ }^{55}$

Mixed though the terminology is, it seems clear what is being suggested. A PSO commander, and PSO training, must draw the basic IHL distinction between combatants and noncombatants. In addition to a force's IHL obligations towards the non-combatants, human 
rights obligations will also exist. The PSO force will therefore have more obligations towards non-combatants than merely keeping itself within the rules of IHL. On the other hand, the text says nothing to suggest that the mission's legal relationship with combatants goes beyond IHL.

Some more light can be shed on the issue by introducing another prominent feature of the Doctrine and, for that matter, of the training policy as well. Both speak repeatedly of the different elements of a peacekeeping mission (once again following the Capstone in this regard). ${ }^{56}$ They refer to the division between military and civilian elements, or between military, police and civilian elements, or a more elaborate typology along these lines. For example: "[a] crisis response or peace support operation will therefore generally include political, diplomatic, military, and civilian (including police, rule of law and civilian administration) and humanitarian efforts to control any conflict and to promote reconciliation, the re-establishment of effective government and a self-sustaining peace". ${ }^{57}$

This asks us to picture the PSO commander at the head of a "composite response" and suggests an equally composite way of thinking about the mission's legal regulation. The simplest version of this argument sees the military part of a mission operating in terms of IHL and seeking to relate only to combatants, while the other parts of the mission operate in terms of IHRL as well, and seek to operate only in relation to non-combatants. But that is too simple, most obviously (for present purposes) because the Doctrine explicitly contemplates that force will be used to prevent "abuses" of "basic human rights", and so the military part of the mission apparently has human rights goals. (It is true that the abuses to which it refers could often also be understood legally as violations of IHL as well, but the Doctrine generally speaks of "human rights" in this regard, as noted).

A more promising interpretation asks us to picture a PSO commander operating in terms of a mandate that includes human rights objectives. The different components of the mission give the commander different possible tools to deploy to fulfil it. When she makes a calculation that the aims of the mandate are best achieved by the use of military force, the commander deploys the military component. That use of force (assuming it is sufficiently intense) occurs from moment to moment within the framework of IHL, in relation to combatants and non-combatants alike. However, IHRL is also present, in two respects. The PSO commander must make constant determinations about the scope and duration of the deployment of the military component, given the risk that civilians will be harmed or the mandate's ends otherwise impaired. Furthermore (recall the reference to PSOs being "appropriately trained"), military personnel are supposed to be trained for a mission understood in terms of human rights objectives. Sub-level commanders with responsibilities for keeping the force on-mission are therefore obliged to keep IHRL interests in mind, and individual peacekeepers are supposed to act within the scope of training that incorporated IHRL concerns.

Effectively, this interpretation asks us to separate ends from means. The actual use of military means, the pointing and firing of weapons, is governed by IHL. But training and institutional command structures seek to ensure that this IHL-governed use of force does not operate in ways that undermine the mission objectives, and those objectives are specified, inter alia, in terms of human rights. Commanders must make constant judgments 
about whether the use of force is undermining the mission's ends, and soldiers are trained with rights in mind.

\section{A narrowed lex specialis?}

This framing makes quite good practical sense of the Doctrine's arguments. It coheres with the idea of civilian actors making decisions to use military tools to achieve carefully constrained peacekeeping ends, an idea upon which the Doctrine repeatedly insists. It also coheres with the decision to permit select peacekeeping forces to act like belligerents, actively entering the fray to achieve specific, offensive objectives, as is the case with the Strategic Intervention Brigade in the DRC. This understanding of military force is readily understood as an IHL-governed tool to be deployed by civilians making calculations about how best to protect rights. But how exactly should we legally understand a situation in which a peacekeeper is not supposed to think of himself as constrained by IHL and IHRL, but by IHL plus his training and orders, which incorporate IHRL and its concerns indirectly?

A plausible legal interpretation of this position works in terms of the logic of what a lex specialis is. The usual lex specialis argument, in relation to IHL and IHRL, is that IHL is the body of law designed for armed conflicts and should therefore apply at such times. However that argument is based on IHL having a better "fit" in that situation by virtue of being more narrowly designed for its peculiarities. Thus, we might argue that IHL does indeed enjoy a better fit with the activity of peacekeepers pointing and firing weapons than IHRL does. However it does not enjoy a better fit with other parts of the peacekeeping context, as argued in the previous sections. So the lex specialis logic has different, narrower implications for the application of IHL to peacekeepers using military force in an armed conflict than it does for ordinary belligerents. IHL does not displace IHRL's application to training or non-military activities, which are informed by concerns for human rights, but only its application to moment by moment military decisions about pointing and shooting, areas in which IHRL, and its sometimes non-derogable provisions, might be seen to enjoy less fit.

Nuanced lex specialis arguments of this sort are gaining traction among scholarly commentators. ${ }^{58}$ This particular argument also at least coheres with the UN's position, in terms of which peacekeepers are combatants for the purposes of IHL only for as long as they use force (at least in an international armed conflict, the position in non-international armed conflicts being less clear). ${ }^{59}$ It also explains the Doctrine. If one were thinking along lines like these, then the otherwise rather legally schizophrenic talk of the human rights of non-combatants quoted earlier would make perfect sense, since the mission's goals include protecting the IHRL rights of non-combatants by using IHL-governed force against combatants that threaten them, and so the combatant / non-combatant distinction is the natural way to direct not only the use of force but also the mission's rights-based obligations.

\section{TWO OBJECTIONS}

This narrowed, compartmentalized lex specialis approach is, the author submits, the best legal reconstruction of the thinking that appears to lie behind the Doctrine (and, to a lesser 
extent, the briefer training manual). The question for the final part of this article is whether this is, after all, a feasible legal approach for AU peacekeeping. The attempt at compartmentalization attracts important objections, and this article offers two different further framings of the lex specialis argument to respond to them.

\section{Blurred lines and the purposive influence of human rights}

The Doctrine is sensibly sceptical about the idea of drawing sharp distinctions between military and non-military spheres of action, but it underestimates the extent of the objection this represents to its understanding. As noted earlier, the Guidelines seem to treat IHRL obligations in peacekeeping contexts as somewhat separate from IHL and the use of force, but do not elaborate. The Doctrine, by contrast, takes the position that a clear division of functions will not be possible in several possible scenarios. For example, "the military may ... be engaged in providing humanitarian assistance". In longer term missions, it might be involved in reforming domestic military forces. ${ }^{60}$ In serious cases, it may have to play a role in assisting police and civilian authorities to re-establish order after a conflict. ${ }^{61}$ In each case, the military will be doing things other than combat, and that activity might be closely related to combat or occur during it. The problem the Doctrine seems to have in mind here is the familiar one of targeting: once military peacekeepers start using force, it becomes harder for the opposing belligerents to distinguish between military peacekeepers engaged in hostilities who may be targeted, on the one hand, and military peacekeepers not engaged in hostilities and non-military peacekeepers, who enjoy non-combatant status. It also becomes less likely that opposing belligerents will try to observe the distinctions. The problem is exacerbated the more military peacekeepers assist with non-military tasks or operate alongside non-military personnel.

If this were the true extent of the objection, however, one might be understandably inclined to dismiss it on pragmatic grounds: the lines of peacekeeping missions are not always going to be neat, and so the legal lines will not always be neat either and one must simply do the best one can to maintain them. Thus the Doctrine argues that both the overall military profile and military involvement in non-military matters should be kept to a minimum, and that military actors should only be involved in activities like policing in significantly unstable contexts, simply trying to minimize problems that will inevitably arise in peacekeeping missions. ${ }^{62}$

This argument, however, is hard to square with the pervasive extent to which the Doctrine itself apparently contemplates that concerns about rights should inform PSO missions. If human rights are supposed to inform command decisions, and if they are also supposed to inform training, then presumably military actors all the way down the chain of command will need to keep these concerns constantly in mind. If so, what is left even of the supposedly narrowed compartment of point and shoot decisions where IHL is supposed to govern alone? The Doctrine addresses the difficulties of the separation between military and non-military peacekeepers, and between military peacekeepers engaged and not engaged in the use of force. However it simply seems to assume less plausible separations between military training and military action, and between the concerns of the commander and the orders that go down the chain of command until they culminate in the actual use of weapons. Put another way, we do, in principle, want the separation between a mission's 
relations with civilians and its relation to armed belligerents, if we can have it, though we recognize this will probably be imperfectly achieved in practice. A legal framing that compartmentalizes civilian relations (where IHRL finds application) and combatant ones (where only IHL does) therefore holds appeal as an ideal to be adhered to as much as circumstances permit. However we do not, in principle, desire a separation between training and the mission's imperatives (both of which are supposed to be pervasively influenced by human rights concerns), and point and shoot decisions. As a result, whereas the first sort of division might be an appealing ideal that is just imperfectly realized in practice, the second is in principle an unappealing ideal, to be discarded before we even get to pragmatic questions about its implementation.

\section{IHRL as (another) lex specialis}

One might finesse the first objection by exploiting the vagaries of the lex specialis doctrine. ${ }^{63}$ If IHL, as a lex specialis, is understood to preclude the application of IHRL, then this will always sit uneasily with the idea that IHRL-related imperatives should be pervasive. However if IHL, as a lex specialis, is understood to give effect to IHRL in a specialized context, this fits with the idea that peacekeeping missions are ultimately about protecting rights, and we have a reason continuously to interpret the specific IHL rules in terms of the general IHRL purposes. ${ }^{64}$ Of course, the original purpose of IHL as a body of law was not to give effect to IHRL-based peacekeeping goals, so the argument here amounts to a reinterpretation of IHL's status as a lex specialis in light of the purposes of peacekeeping activity as the Doctrine seems to understand them. It fits with the Doctrine's persistent concern that military force should not be used in ways that depart from the IHRL-related imperatives of training and mandates. It is true that it will not always be easy to decide what IHL-in-light-of-IHRL requires, and that this type of question is often truly the province of the judge in the slowness of the courtroom rather than a soldier in the rapidity of combat. ${ }^{65}$ However this is again a practical objection, to be met with the pragmatic responses the Doctrine seems inclined to give; it is no longer an objection against the basic form of the answer.

However, this understanding, like the Doctrine itself, assumes that IHL is the lex specialis, with IHRL as the less specialized set of norms having some subsidiary effect. It is not at all clear that this assumption holds up to scrutiny in light of modern IHRL. As the author has examined in detail elsewhere, rights instruments in both the African regional context and the general international one increasingly make specific provision for armed conflict situations, notably in relation to women's and children's rights. ${ }^{66}$ In this context, the logic of lex specialis gives us little reason to think that IHL, and not these IHRL provisions, should generally govern in situations of armed conflict: both norms are at least putatively comparably specialized. This is especially the case in the peacekeeping context, where human rights concerns are especially important, while IHL is less obviously specially designed for the activity.

At first glance, it may not look implausible to separate these rights-based concerns from the imperatives of conflict. The Doctrine, for example, offers the following gloss on the "human rights" component of a PSO, off to one side of the fighting: "[f]acilitate the promotion and protection of human rights, with particular attention to women, children and other 
vulnerable purposes, through: human rights monitoring and reporting, advise [sic] and education to the parties to the conflict, monitor and advice [sic] new institutions on human rights issues". ${ }^{67}$

However, it is doubtful that this separation is feasible in light of either the reality of African peacekeeping or the nature of the IHRL duties concerned. To take what is probably the strongest example, IHRL creates special duties in relation to child soldiers, and there is no separating that obligation from African combat scenarios where child soldiers are sadly a common presence. One might consider that duty outweighed or lessened in the heat of combat, but that is not the same as saying that it does not apply during combat. ${ }^{68}$ Duties like this are specialized pieces of law that find application nowhere except in conflict situations. Lex specialis is no basis to preclude their application or confine them to the status of subsidiary interpretative norms. Even the view on which IHRL constantly informs the application of IHL to peacekeeping is inadequate to these duties: the only legal framing that fits is one that includes the application of at least some parts of IHRL to every part of a PSO.

\section{NEXT STEPS}

In summary, both the African Standby Force's draft Doctrine and (to a still greater extent) the draft Guidelines for the Protection of Civilians suggest that the AU is like the UN in being fairly vague and cautious about the application of IHRL to its peacekeepers. However, the Doctrine's own positions, especially when read alongside other international and African IHRL instruments, imply a far more extensive application of IHRL to peacekeepers than is captured by standard lex specialis arguments. This is an inescapable result of the admirable concern for rights, combined with the recent willingness to take forceful action in the name of this concern, which is an important theme of current African attitudes to conflict and peacekeeping.

This conclusion means that more work is needed to integrate IHL and IHRL in the African context. Fragmentation is inevitable and sometimes valuable when new legal frameworks are emerging. ${ }^{69}$ However, too little has been done so far to bring core IHRL instruments together with the emerging African Peace and Security Architecture, or to cash out the implications of that architecture. As we have seen, the implications of doing so represent a strong objection to the legal understanding, based on an uncritical assumption of lex specialis arguments about IHL, that the current form of the Doctrine seems to hold. Indeed, if this article's arguments are correct, lex specialis may in fact be of little assistance in pursuing these answers. As one commentator on the doctrine has observed, "lex specialis does not provide any criteria to guide the decision whether one area of law is generally more important than another ... In the end, the question of ... which rules to give primacy to ... is a highly political and value-related issue". ${ }^{70}$

Deciding how a peacekeeper should confront an army including armed children, or how a commander should engage a belligerent, civilian-threatening force that also contains many vulnerable women and girls, is not a matter of applying abstract legal doctrines. In confronting such questions, it is important to be aware of the degree to which AU institutions (and African states) have already made value choices that give far more scope to 
IHRL than is currently acknowledged in the AU policy documents on PSOs, as this article has argued. However, the arguments about the application of bodies of law considered in this article can take us little further than that. The need for more work to spell out the implications of IHRL duties for the conduct of PSOs that involve military force is therefore patent. The AU's efforts, above all in the draft Doctrine, are important, but their engagement with legal issues remains limited, as does, as a result, their ability to respond to these problems.

\section{NOTES}

${ }^{1}$ A Jeng Peacebuilding in the African Union: Law, Philosophy and Practice (2012, Cambridge University Press) especially at 175-77, 180-201, 282-84 and 286-92; see also C Murray Human Rights in Africa: From the OAU to the African Union (2005, Cambridge University Press).

${ }^{2}$ This power is asserted in the face of art 53(1) of the UN Charter that states: “... no enforcement action shall be taken under regional arrangements or by regional agencies without the authorization of the Security Council". See further E de Wet "Regional organizations and arrangements and their relationship with the United Nations: The case of the African Union" in M Weller (ed) The Oxford Handbook on the Use of Force (2014, Oxford University Press) 314 .

${ }^{3}$ Protocol on Amendments to the Constitutive Act of the African Union, opened for signature 11 July 2003 (not yet in force), at 2.

${ }^{4}$ See the documents discussed below.

${ }^{5}$ See for example D Shraga "The interplay between human rights and international humanitarian law in UN operations" in E de Wet and J Kleffner (eds) Convergence and Conflicts of Human Rights and International Humanitarian Law in Military Operations (2014, Pretoria University Law Press) 211 at 212-13; T Muruthi "The African Union's evolving role in peace operations: The African Union Mission in Burundi, the Africa Union Mission in Sudan and the African Union Mission in Somalia" (2008) 17 African Security Review 70 ; SC Breau "The impact of the responsibility to protect on peacekeeping" (2006) 11 Journal of Conflict \& Security Law 429 ; Jeng Peacebuilding, above at note 1, chaps 7-8.

${ }^{6}$ See SC res 2098, UN SCOR, 68th sess, 6943rd meeting, UN doc S/RES/2098 (28 March 2013); SC res 2136, UN SCOR 68th sess, 7017th meeting, UN doc S/RES/2136 (30 January 2014); SC res 2147, UN SCOR, 68th sess, 7150th meeting (28 March 2014).

${ }^{7}$ UN United Nations Peacekeeping Operations: Principles and Guidelines (2008, United Nations Secretariat) (Capstone).

${ }^{8}$ See sources cited in note 21 below.

${ }^{9}$ The Responsibility to Protect is an emerging international legal doctrine under which all states have obligations to respond to genocide, war crimes, ethnic cleansing and crimes against humanity whenever they occur.

${ }^{10}$ See for example AE Cassimatis "International humanitarian law, international human rights law and the fragmentation of international law" (2007) 56 International and Comparative Law Quarterly 623 at 630, noting that conflict between the peremptory norms of the two bodies of law is "probably only a theoretical possibility".

${ }^{11}$ See the well-known statements by the International Court of Justice on the issue in Legality of the Threat or Use of Nuclear Weapons ICJ Rep 1996 226, para 25 and Legal Consequences of the Construction of a Wall in 
Occupied Palestinian Territory ICJ Rep 2004 136, para 106; the court subsequently cited these decisions without specifically referring to IHL as the lex specialis in Armed Activities on the Territory of the Congo (Democratic Republic of the Congo v Uganda) ICJ Rep 2005 168, para 216. Useful discussions from the extensive literature on these statements and related sources include M Dennis "ICJ advisory opinion on construction of a wall in the occupied Palestinian territory: Application of human rights treaties extraterritorially in times of armed conflict and military occupation" (2005) 99 American Journal of International Law 119 ; C Droege "The interplay between international humanitarian law and IHRL in situations of armed conflict" (2007) 40 Israel Law Review 310 ; N Prud'homme "Lex specialis: Oversimplifying a more complex and multifaceted relationship?" (2007) 40 Israel Law Review 355 ; J Sarkin "The historical origins, convergence and interrelationship of international human rights law, international humanitarian law, international criminal law and public international law and their application since the nineteenth century" (2007) 1 Human Rights and International Legal Discourse 125 ; M Milanović "Norm conflicts, international humanitarian law and human rights law" (2009) 14 Journal of Conflict and Security Law 459 ; OA Hathaway et al. "Which law governs during armed conflict? The relationship between international humanitarian law and human rights law" (2011-12) 96 Minnesota Law Review 1883 ; D Jinks "International human rights law in time of armed conflict" in A Clapham and P Gaeta (eds) The Oxford Handbook of International Law in Armed Conflict (2014, Oxford University Press) 656 ; I Scobbie "Human rights protection during armed conflict: What, when and for whom?" in de Wet and Kleffner (eds) Convergence and Conflicts, above at note 5, 3; and P Alston , J Morgan-Foster and W Abresch "The competence of the UN Human Rights Council and its special procedures in relation to armed conflicts: Extrajudicial executions in the "War on Terror" (2008) 19 European Journal of International Law 183 at 191-97. It should be noted that, since the publication of the last-mentioned article, the US has changed its position on the issue of the application of IHRL during conflict that the article discusses, and the US now accepts that the IHRL and IHL "are in many respects complementary and mutually reinforcing"; see Fourth Periodic Report of the USA to the UN Committee on Human Rights Concerning the International Covenant on Civil and Political Rights (30 December 2011), para 507.

${ }^{12}$ The African Standby Force, composed of troop contributions from member states, is the force contemplated by the founding instrument of the AU Peace and Security Council to enable it to conduct peace missions and other interventions under the AU Constitutive Act. See Protocol Relating to the Establishment of the Peace and Security Council of the African Union (AU PSC Protocol), art 13.

${ }^{13}$ African Standby Force "Peace support operations doctrine" (draft dated November 2006), available at: <http://civilian.peaceau.org/index.php?option=com_docman\&task=doc_download\&gid=120\&ltemid=61\&lang =en> (last accessed 15 December 2016).

${ }^{14}$ It joins a number of other efforts to re-think peacekeeping doctrine in light of the developments of recent years; see further for example R Murphy UN Peacekeeping in Lebanon, Somalia and Kosovo: Operational and Legal Issues in Practice (2009, Cambridge University Press) at 16-21.

${ }^{15}$ AU PSC Protocol, art 7(1)(b)-(d).

${ }^{16}$ See especially AU “African Peace and Security Architecture (APSA): 2010 assessment study", available at: <http://www.peaceau.org/uploads/report-of-the-apsa-assessment-study-july-oct-2010-eng.pdf> (last accessed 15 December 2016) and AU “Indicative elements for the APSA Roadmap 2011-13", available at: <http://www.peaceau.org/uploads/indicative-elements-apsa-roadmap-2011.pdf> (AU Indicative Elements) (last accessed 15 December 2016). For recent updates, see AU / EU “Joint communiqué" (ninth meeting of the Joint Coordination Committee of the African Peace Facility, Addis Ababa, 3 June 2014), available at: <http://www.peaceau.org/uploads/final-jcc-communique-au-rm.pdf> (last accessed 15 December 2016); AU / UN "Joint communiqué" (eighth UN-AU Joint Task Force meeting on peace and security in Africa, Addis Ababa, 2 February 2014), available at: <http://www.peaceau.org/uploads/au-un-8-jtf-communiquy-02-02-2014.pdf> (last accessed 15 December 2016); AU PSC "Information note on the implementation status of the decision of the Assembly of the Union on the establishment of the African capacity for immediate response to crises" PSC/MIN/3(CCCLXXXVII) (29 July 2013), available at: <http://www.peaceau.org/uploads/psc-387-report-asfcaric-29-07-2013-en.pdf> (last accessed 15 December 2016); and "Progress report on the implementation of the conclusions of the Nouakchott ministerial meeting of 17 March 2013" (second ministerial meeting on the enhancement of security cooperation and the operationalization of the African Peace and Security 
Architecture in the Sahelo-Saharan Region, Ndjamena, Chad, 11 September 2013), paras 11-12, available at: <http://www.peaceau.org/uploads/auc-report-ndjamena-ministerial-meeting-11-09-2013.pdf> (last accessed 15 December 2016).

${ }^{17} \mathrm{AU}$ Indicative Elements, sec 2.

${ }^{18} \mathrm{AU}$ "Report of the Commission on the 2 nd conference of ministers of defence and security on the operationalisation of the African Standby Force" (24-28 June 2008, Sharm El Sheikh, Egypt) EX.CL/427 (XIII), available at: <http://www.peaceau.org/uploads/ex-cl-427-xiii-e.pdf> (2nd Operationalisation Report) (last accessed 15 December 2016).

${ }^{19}$ See <http://www.peaceau.org> (last accessed 15 December 2016).

${ }^{20}$ Although this article will cast the net somewhat wider still, it is also worth noting that the International Law Commission's emerging approach to the sources relevant to identifying customary law treats "resolutions, declarations, recommendations and decisions" of regional organizations as potentially valuable evidence. See the first report of the special rapporteur, Michael Wood, International Law Commission, report of the 65th session (2013) A/68/10, para 95.

${ }^{21}$ See for example Doctrine, chap 2, secs 9 and 22 and chap 4, secs 4-6 and 35; 2nd Operationalisation Report at 51; AU "Policy framework for the establishment of the African Standby Force and the Military Staff Committee" (document adopted by the third meeting of African chiefs of defense staff, 15-16 May 2003, Addis Ababa) Exp/ASF-MSC/2(1), especially secs 1.4(a), 2.2 and 2.12-2.21, available at:

<http://www.peaceau.org/uploads/asf-policy-framework-en.pdf> (last accessed 15 December 2016); see also J Sarkin "The responsibility to protect and humanitarian intervention in Africa" (2010) 2 Global Responsibility to Protect 371 ; T Muruthi "The African Union at ten: An appraisal” (2012) 111 African Affairs 662 ; de Wet "Regional organizations", above at note 2.

22 JG Stewart "Towards a single definition of armed conflict in international humanitarian law: A critique of internationalized armed conflict" (2003) 85 International Review of the Red Cross 313 especially at 319-23 (with an open question at 332-33 as to how many African conflicts might be said to have been internationalized); S Sivakumaran "Re-envisaging the international law of internal armed conflict" (2011) 22 European Journal of International Law 219 ; G Blum "Re-envisaging the international law of internal armed conflict: A reply to Sandesh Sivakumaran" (2011) 22 European Journal of International Law 265 ; S Sivakumaran "Re-envisaging the international law of internal armed conflict: A rejoinder to Gabriella Blum" (2011) 22 European Journal of International Law 273 ; Scobbie "Human rights protection", above at note 11 at 8-13.

${ }^{23}$ This reflects how, especially in contexts where legal details are not the foremost concern, substantive issues tend to cut across standard IHL distinctions. See further A Duxbury "Drawing lines in the sand: Characterising conflicts for the purposes of teaching international humanitarian law" (2007) 8 Melbourne International Law Journal 259 .

${ }^{24}$ See for example O Engdahl "The status of peace operations personnel under international humanitarian law" (2008) 11 Yearbook of International Humanitarian Law 109 ; S Wills Protecting Civilians: The Obligations of Peacekeepers (2009, Oxford University Press), chaps 2-3; O Engdahl "Compliance with international humanitarian law in multinational peace operations" (2010) 78 Nordic Journal of International Law 513 ; D Fleck "The law applicable to peace operations" in Clapham and Gaeta (eds) The Oxford Handbook, above at note 11, 206 at 234-38; M Zwanenburg "The interplay between international humanitarian law and international human rights law in peace operations" in de Wet and Kleffner Convergence and Conflicts, above at note 5,153 .

${ }^{25}$ On the "very sparse" literature on these issues in relation to African (judicial and quasi-judicial) institutions, see F Viljoen "The relationship between international human rights and humanitarian law in the African human rights system: An institutional approach" in De Wet and Kleffner id, 303 at 303. On these issues in other 
contexts for the purposes of drawing analogies, see for example F Mégret and F Hoffmann "The UN as a human rights violator? Some reflections on the United Nations changing human rights responsibilities" (2003) 25 Human Rights Quarterly 314 ; A Reinisch "Developing human rights and humanitarian law accountability of the Security Council for the imposition of economic sanctions" (2001) 95 American Journal of International Law 851 ; A Reinisch "Securing the accountability of international organizations" (2001) 7 Global Governance 131 ; see also the critique by Shraga "The interplay", above at note 5 at 214-15.

${ }^{26}$ AU PSC Protocol, arts 3(f), 4(c) and $7(1)(\mathrm{m})$. Its obligations are of course stricter in relation to breaches of IHL that constitute war crimes, genocide and crimes against humanity.

${ }^{27} 51$ African countries have ratified the four main Geneva Conventions and the International Covenant on Civil and Political Rights; 49 have ratified Additional Protocol I. The relationship between the responsibility of the sending state and the control it exercises has been the subject of important recent European developments. See especially Hasan Nuhanović $v$ the Netherlands ILDC 1742 (NL 2011); Al-Jedda $v$ United Kingdom (app no 27021/08, 7 July 2011); and see further for example T Dannenbaum "Translating the standard of effective control into a system of effective accountability: How liability should be apportioned for violations of human rights by member state troop contingents serving as United Nations peacekeepers" (2010) 51 Harvard International Law Journal 113 ; B Boutin "Responsibility of the Netherlands for the acts of Dutchbat in Nuhanović and Mustafić: The continuous quest for a tangible meaning for 'effective control' in the context of peacekeeping" (2012) 25 Leiden Journal of International Law 521.

${ }^{28}$ See for example the AU's most recent (draft) position in “The African Standby Force: Draft Maputo strategic work plan (2016-2020)", available at: <http://www.peaceau.org/uploads/draft-asf-strategic-work-plan-20162020-.pdf> (last accessed 16 January 2017).

${ }^{29} \mathrm{AU}$ "Proposed guidelines for the protection of civilians in African Union peace support operations for considerations [sic] by the African Union" at 9, available at: <http://www.operationspaix.net/DATA/DOCUMENTTEXTE/8763.pdf> (last accessed 15 December 2016).

${ }^{30}$ Id at 6.

31 "Policy framework for the establishment of the African Standby Force and the Military Staff Committee" (adopted by the third meeting of African chiefs of defense staff, 15-16 May 2003, Addis Ababa), secs 2.122.13.

${ }^{32}$ Shraga "The interplay", above at note 5 at 214.

${ }^{33}$ Doctrine, chap 3, secs 24-25.

${ }^{34}$ Id, chap 3, sec 13.

${ }^{35}$ Id, chap 3, sec 15.

${ }^{36}$ 2nd Operationalisation Report at 22. The report was endorsed by the Executive Council; see "Decision on the report of the Commission on the Operationalization of the African Standby Force", EX.CL/Dec.430 (XIII), available at: <http://www.peaceau.org/uploads/ex-cl-dec-430-xiii-e.pdf> (last accessed 15 December 2016).

${ }^{37} \mathrm{~J}$ Fowkes "Armed conflicts and the lex specialis debate in Africa: Implications of the emerging women's and children's rights regimes" (forthcoming).

${ }^{38}$ Doctrine, chap 3, sec 5 .

${ }^{39}$ Id, sec 77. 
${ }^{40}$ Id, sec 91.

${ }^{41}$ Capstone, above at note 7 at $87-88$.

${ }^{42}$ Doctrine, chap 3, sec 11.

${ }^{43}$ Capstone, above at note 7 at 32 and 36-37.

${ }^{44}$ Doctrine, chap 3, sec 6.

${ }^{45}$ Id, chap 3, sec 6 .

${ }^{46}$ That is not to say, of course, that strict regimes of legal punishment, such as those contemplated by international criminal law, are necessarily the best way to achieve post-conflict goals, an important question not to be begged. See further H Charlesworth "Law after war" (2007) 8 Melbourne Journal of International Law 233.

${ }^{47}$ Doctrine, chap 3, sec 37.

${ }^{48}$ Id, sec 22-23.

${ }^{49}$ Capstone, above at note 7 at $14-15$.

${ }^{50}$ Doctrine, chap $3, \sec 36$.

${ }^{51}$ Art 3 of the Geneva Conventions "offers minimum protection to persons taking no active part" in "armed conflict not of an international character".

${ }^{52}$ Capstone, above at note 7 at $33-34$

${ }^{53}$ Doctrine, chap 3, sec 38 .

${ }^{54}$ Id, sec 3.

${ }^{55} \mathrm{Id}, \sec 33$

${ }^{56}$ Capstone, above at note 7 at $14-15$

${ }^{57}$ Doctrine, chap 1, sec 5.

${ }^{58}$ See for example Prud'homme "Lex specialis", above at note 11 at 386-92; M Sassòli and LM Olson "The relationship between international humanitarian law and human rights law where it matters: Admissible killing and internment of fighters in non-international armed conflicts" (2008) 90 International Review of the Red Cross 599 ; Hathaway et al "Which law governs", above at note 11 at 1906-08 and 1910-23; D Bethlehem "The relationship between international humanitarian law and international human rights law in situations of armed conflict" (2013) 2 Cambridge Journal of International and Comparative Law 180 . See also Sivakumaran "Reenvisaging", above at note 22 at 240-42.

${ }^{59}$ See Shraga "The interplay", above at note 5 at 213; Droege "The interplay", above at note 11 at 344-47.

${ }^{60}$ Doctrine, chap 2, sec 20.

${ }^{61}$ Id, sec 21. 
${ }^{62}$ Id, chap 4, sec 41.

${ }^{63}$ On the uncertainties of the lex specialis doctrine in the practice of international tribunals, see especially $\mathrm{A}$ Lindroos "Addressing norm conflicts in a fragmented system: The doctrine of lex specialis" (2005) 74 Nordic Journal of International Law 42 ; and the study led by Martti Koskenniemi: International Law Commission "Study of the function and scope of the lex specialis rule and the question of 'self-contained regimes'": UN doc ILC(LVI)/SG/FIL/CRD.1; and International Law Commission "Report of the fifty-sixth session" (2004) A/59/10, paras 303-30.

${ }^{64}$ See for example $\mathrm{H}$ Kruger "A conflict of norms: The relationship between humanitarian law and human rights law in the ICRC customary law study" (2006) 11 Journal of Conflict \& Security Law 265.

${ }^{65}$ Sassòli and Olson "The relationship between", above at note 58 at 613.

${ }^{66}$ Fowkes "Armed conflicts", above at note 37.

${ }^{67}$ Doctrine, chap 4, sec 68 .

${ }^{68}$ Fowkes "Armed conflicts", above at note 37.

${ }^{69}$ Cassimatis "International humanitarian law", above at note 10 at 638.

${ }^{70}$ Lindroos "Addressing norm conflicts", above at note 63 at 66. 